\title{
Publisher Correction: Evolutionary adaptations to new environments generally reverse plastic phenotypic changes
}

Wei-Chin $\mathrm{Ho}^{1,2} \&$ Jianzhi Zhang (1) ${ }^{1}$

Correction to: Nature Communications https://doi.org/10.1038/s41467-017-02724-5, published online: 24 January 2018

The originally published HTML version of this Article contained errors in the three equations in the Methods sub-section 'Metabolic network analysis', whereby the Greek letter eta $(\eta)$ was inadvertently used in place of beta $(\beta)$ during the production process. These errors have now been corrected in the HTML version of the Article; the PDF was correct at the time of publication.

Published online: 21 February 2018

\begin{abstract}
(c) (1) Open Access This article is licensed under a Creative Commons Attribution 4.0 International License, which permits use, sharing, adaptation, distribution and reproduction in any medium or format, as long as you give appropriate credit to the original author(s) and the source, provide a link to the Creative Commons license, and indicate if changes were made. The images or other third party material in this article are included in the article's Creative Commons license, unless indicated otherwise in a credit line to the material. If material is not included in the article's Creative Commons license and your intended use is not permitted by statutory regulation or exceeds the permitted use, you will need to obtain permission directly from the copyright holder. To view a copy of this license, visit http://creativecommons.org/licenses/by/4.0/.
\end{abstract}

(c) The Author(s) 2018

\footnotetext{
${ }^{1}$ Department of Ecology and Evolutionary Biology, University of Michigan, Ann Arbor, MI 48109, USA. ${ }^{2}$ Present address: Center for Mechanisms of Evolution The Biodesign Institute, Arizona State University, Tempe, AZ 85287, USA. Correspondence and requests for materials should be addressed to

J.Z. (email: jianzhi@umich.edu)
} 